\title{
147 \\ Chapter 5
}

\section{International Germplasm Collection, Conservation, and Exchange at ICRISAT ${ }^{1}$}

\author{
MELAK H. MENGESHA ${ }^{2}$
}

Germplasm is the most important raw material for any crop improvement program, and yet humankind continues to be faced with the extinction of this invaluable and irreplaceable resource. One of the best descriptions of genetic resources is given by Mehra and Arora (16) who stated, "Plant genetic resources represent the sum total of diversity accumulated through years of evolution under domestication and natural selection". Genetic manipulation (3) is advancing at a fast pace and the process may be even more accelerated by the application of genetic engineering techniques. But nothing can be achieved, even by genetic engineering, unless those desirable genes are at our disposal. Jain (11) considered germplasm as part of human biological heritage without whose free exchange present-day farm productivity would not have been possible. In this regard, the International Agricultural Research Centers strategically located at regions of rich crop diversity are in a unique position to collect and conserve germplasm and make it readily available to all scientists throughout the world.

\footnotetext{
${ }^{1}$ Contribution from the International Crops Research Institute for the Semi-Arid Tropics, Andhra Pradesh, India.

'Principal germplasm botanist and leader, Genetic Resources Unit, International Crops Research Institute for the Semi-Arid Tropics (ICRISAT), Patancheru P.O. 502 324, Andhra Pradesh, India.
} 
In the area of genetic resources, International Crops Research Institute for the Semi-Arid Tropics' (ICRISAT) major objectives are to:

1. Collect and assemble the germplasm of the cultivated and wild relatives of its mandated crops, namely:

Sorghum - Sorghum bicolor (Linn.) Moench

Pearl millet - Pennisetum americanum (L.) Leeke

Pigeon pea - Cajanus cajan (L.) Huth

Chickpea - Cicerarietinum (L.)

Groundnut - Arachis hypogaea (L.)

The institute also collects and conserves the germplasm of the following six minor millets:

Finger millet - Eleusine coracana (L.) Gaertn.

Foxtail millet - Setaria italica (L.) P. Beauv.

Proso millet - Panicum miliaceum $\mathrm{L}$.

Little millet $\quad-P$. sumatrense Roth

Barnyard millet - Echinochloa crusgalli (L.) P. Beauv.

Kodo millet - Paspalum scrobiculatum L.

2. Characterize, evaluate, and document the germplasm.

3. Maintain and rejuvenate the germplasm without marked alteration of the original genotype or mixture of genotypes.

4. Serve as a world repository of the germplasm of ICRISAT mandated crops and the six minor millets by conserving the germplasm in medium and long-term cold storage.

5. Distribute and exchange germplasm for present and future utilization.

\section{GERMPLASM COLLECTION}

Germplasm collection has lately gained due recognition. However, actual collection work is still lagging behind. If we are to avert food shortages and subsequent famines, we have to accelerate crop improvement programs, starting with collection and conservation of vanishing germplasm. The problem of food shortage and the need for urgent crop improvement programs is most alarming in the developing world. However, it is in the developing countries where the greatest diversity of our germplasm still exists, although it is gradually dwindling. Furthermore, germplasm in itself does not provide higher productivity. It needs to be explored and utilized more effectively in crop improvement programs under different environmental conditions. The time to collect the traditional landraces is now, before they are replaced by newly bred, highyielding cultivars (5). In some cases it is already too late (17).

One source of concern is that many germplasm collection missions have been launched at about the prime maturity time of the crops to be collected. As a result, the farmers have often already harvested and consumed most of the early maturing types. We have to change our collection strategies so that we will be able to collect sufficient samples of early maturing types that may prove vital in averting future famines. The succof of any germplasm collection mission largely depends on the collector's 
Table 1. Germplasm collection, conservation, and distribution at ICRISAT (as of 1 May 1983).

\begin{tabular}{|c|c|c|c|c|c|c|c|}
\hline Crop & $\begin{array}{c}\text { No. of } \\
\text { accessions } \\
\text { con- } \\
\text { served }\end{array}$ & $\begin{array}{c}\text { No. of } \\
\text { samples } \\
\text { in } \\
\text { transit }\end{array}$ & $\begin{array}{c}\text { No. of } \\
\text { accessions } \\
\text { evaluated }\end{array}$ & $\begin{array}{c}\text { No. of } \\
\text { com- } \\
\text { puterized } \\
\text { accessions }\end{array}$ & $\begin{array}{c}\text { No. of } \\
\text { samples } \\
\text { dis- } \\
\text { tributed }\end{array}$ & $\begin{array}{l}\text { No. of } \\
\text { wild } \\
\text { relatives } \\
\text { main- } \\
\text { tained }\end{array}$ & $\begin{array}{l}\text { No. of } \\
\text { countries } \\
\text { repre- } \\
\text { sented }\end{array}$ \\
\hline Sorghun & 22898 & 2175 & 19363 & 7114 & 184025 & 278 & 79 \\
\hline Pearl millet & 16002 & .. & 15388 & 924 & 37944 & 20 & 3 \\
\hline Pigeon pea & 9936 & 345 & 9930 & 9697 & 54836 & 38 & 33 \\
\hline Chickpea & 12950 & .- & 12200 & 11000 & 103899 & 14 & 40 \\
\hline Groundnut & 10248 & 2017 & 9190 & 174 & 33859 & 21 & 80 \\
\hline $\begin{array}{l}\text { Six minor } \\
\text { millets }\end{array}$ & 4512 & 451 & 4295 & .- & 19493 & 6 & 31 \\
\hline Total: & 76546 & 4988 & 70366 & 28909 & 434056 & 377 & -- \\
\hline
\end{tabular}

Table 2. Range of variation in 12 selected characters of sorghum and pearl millet germplasm evaluated at ICRISAT Center, Patancheru.

\begin{tabular}{lcc}
\hline & \multicolumn{2}{c}{ Range of variation } \\
\cline { 2 - 3 } Character & Sorghum & Pearl millet \\
\hline Days to 50\% flowering & $36-199$ & $33-140$ \\
Plant height (cm) & $55-655$ & $35-475$ \\
Peduncle exertion (cm) & $0-55$ & $-21-+30$ \\
Midrib color & White-brown & White-purple \\
Head length (cm) & $2.5-71$ & $6-165$ \\
Head width (cm) & $1-29$ & $1-6.4$ \\
Glume color & Straw-black & Straw-purple \\
Glume covering & Exposed-covered & Exposed-covered \\
Grain color & White-dark brown & White-dark brown \\
l00 grain weight (g) & $0.58-8.5$ & $0.3-1.4$ \\
Tillering (no.) & $1-15$ & $1-210$ \\
Sugar content \% & $12-38$ & $4.9-19.7$ \\
\hline
\end{tabular}

knowledge of the crops, their wild relatives, geographical and political accessibility, proper collection strategies, correct sampling procedures, safe and rapid transfer of the collected material, and timely evaluation and utilization.

The numbers of germplasm accessions assembled by ICRISAT from various countries and samples distributed to several countries are summarized in Table 1. Detailed information is given in the 1980 and 1981 Annual Reports of ICRISAT $(8,9)$. For each of the ICRISAT crops, these accessions represent the largest collection of germplasm assembled at any one place. However, considering the extent of the area devoted to these crops, the present collection is still too small.

The importance of the collected and conserved germplasm depends in part on its genetic diversity. The range of variation in some selected characters of sorghum and pearl millet is given in Table 2. A wide range of variation is also available for pigeon pea, chickpea (Table 3), and groundnut (Table 4). The range of variation was even higher for chickpea evaluated at Hissar, Hayana, India (21). Likewise, a wider range of variation was recorded when 343 pearl millet collections were evaluated 
Table 3. Range of variation in 15 selected characters of pigeon pea and chickpea germplasm evaluated at ICRISAT Center, Patancheru.

\begin{tabular}{|c|c|c|}
\hline \multirow[b]{2}{*}{ Character } & \multicolumn{2}{|c|}{ Range of variation } \\
\hline & Chickpea & Pigeon pea \\
\hline $\begin{array}{l}\text { Growth habit } \\
\text { Stem color } \\
\text { Flower color } \\
\text { Seed color } \\
\text { Seed shape } \\
\text { Days to } 50 \% \text { flowering } \\
\text { Days to maturity } \\
\text { Primary branch per plant (no.) } \\
\text { Secondary branch per plant (no.) } \\
\text { Raceme per plant (no.) } \\
\text { Plant height (cm) } \\
\text { Plant width (cm) } \\
\text { No. of pods per plant } \\
\text { Seed per pod } \\
100 \text { seed weight (g) }\end{array}$ & $\begin{array}{c}\text { erect-semi-spreading } \\
\text { green-purple } \\
\text { white-blue } \\
\text { cream-black } \\
\text { angular-globular } \\
28-96 \\
90-137 \\
-- \\
-- \\
-- \\
16-93 \\
18-70 \\
\text { few-168 } \\
1-2.8 \\
4.9-59.4\end{array}$ & $\begin{array}{c}\text { compact-spreading } \\
\text { green-purple } \\
\text { ivory-purple } \\
\text { white-black } \\
\text { oval-square } \\
55-228 \\
105-260 \\
2-66 \\
0.3-145 \\
10-788 \\
39-400 \\
-- \\
- \\
2-8.5 \\
2.8-26.5\end{array}$ \\
\hline
\end{tabular}

Table 4. Range of variation in 13 selected characters of groundnut germplasm evaluated at ICRISAT Center, Patancheru.

\begin{tabular}{lc}
\hline Character & Range of variation \\
\hline Days to $50 \%$ flowering & $16-58$ \\
Days to maturity & $75-155$ \\
Length of reproductive branch $(\mathrm{mm})$ & $8-122$ \\
Leaflet length $(\mathrm{mm})$ & $24-86$ \\
Leaflet width $(\mathrm{mm})$ & $8-41$ \\
Pod length $(\mathrm{mm})$ & $11-60$ \\
Pod diameter $(\mathrm{mm})$ & $9-27$ \\
No. of seeds per pod & $1-5$ \\
Seed color & Off-white-Dark purple \\
Seed length $(\mathrm{mm})$ & $7-21$ \\
Seed width $(\mathrm{mm})$ & $5-13$ \\
100 seed weight $(\mathrm{g})$ & $19.8-121.5$ \\
Oil content $(\%)$ & $31.8-53.1$ \\
\hline
\end{tabular}

in a multi-locational evaluation program conducted in India and West Africa.

The main purpose of pointing out the range of variation is to underline the importance of collection and exchange of the diverse germplasm that may otherwise be lost. Although, the conserved variation is very useful, it is yet considered small compared to what is available in nature. Unfortunately, its availability in nature cannot be guaranteed in view of the alarming genetic erosion that is taking place around the world. A good example of such genetic erosion is the complete absence of "zera zera" and "Hegari" sorghum landraces in the Geziera Province of Sudan, and their replacement by the newly bred cultivars (17).

\section{CONSERVATION}

The problem of seed conservation probably started soon after we domesticated crops about 10000 to 12000 years ago (5). Until recent years, crop improvement scientists did not much care if their collected 
germplasm were lost, because they could find and recollect such seeds easily (6). Now, there is strong evidence that it is not always easy to find the landraces where they were seen last. If plant breeders want to have a ready supply of germplasm, the time has come for them to rely on man made gene banks. Maintenance and preservation of landraces in protected gene reserves, though desirable in some specific cases, may not be practical or economical. Moreover, safety and continuity cannot be always assured. Therefore, we do not seem to have any other alternative but to collect urgently and conserve our invaluable germplasm in genebanks.

At ICRISAT, over 74000 germplasm accessions of the institute's mandated crops are now conserved in medium-term $\left(+4^{\circ} \mathrm{C}\right.$ and about $30 \%$ relative humidity) cold storage facilities. About $500 \mathrm{~g} \cdot$ seed of each accession is dried to about 5 to $7 \%$ moisture before it is stored. The type of storage chambers used at ICRISAT and the general standards and systems of germplasm technology and conservation have been described by Mengesha and Rao (17) and the IBPGR (10), respectively. More comprehensive reports on viability of seeds and principles and practices of seed storage are given by Roberts (20) and Justice and Bass (12). Long-term cold storage $\left(-20^{\circ} \mathrm{C}\right)$ chambers have been ordered and will soon be installed as part of the ICRISAT gene bank. The latest germination test on conserved seeds showed over $92 \%$ viability after years of storage. All the stored seeds are rejuvenated before their germination drops below $85 \%$ or before the seed quantity reaches a critical level.

It must be stressed here that only those seeds that are harvested from disease-free plants are conserved in the gene bank. Stringent field inspections and laboratory tests are made to ensure storage and distribution of disease and pest-free seeds, with the full cooperation of the Plant Quarantine Division of the Government of India.

\section{EXCHANGE OF GERMPLASM}

The success of international germplasm collection and utilization largely depends on its timely transfer and ease of mobility. Unfortunately, there are many hurdles that a germplasm sample has to pass through before it can reach its destination. From the plant quarantine point of view, it seems there is some tendency to overemphasize the risks involved in the exchange of germplasm. It is true that there is some risk in the transfer of unchecked germplasm from one region to another. It is also important to recognize that many samples may never reach their destination due to certain factors that may not be risky or are of low risk. The dilemma we are in is that many of these germplasm accessions can neither reach their destination nor survive for long in their original, threatened habitat.

It is beyond the scope of this chapter to list and discuss all the risks associated with germplasm exchange. The major diseases, pests, and weeds of importance for quarantine purposes are fairly well known $(4,7$, 19). In general, it is well documented that many of the risks associated with germplasm transfer can be controlled. Khan (13) stated that the aim of plant quarantine is to prevent the introduction of harmful organisms to a new area. Likewise, it may be stated that the aim of germplasm collection and exchange is to conserve and introduce useful germplasm without 
Table 5. Number of samples of ICRISAT crops received by the CPPTI during 1981 to 1982 compared with the number released and detained.

\begin{tabular}{|c|c|c|c|c|c|}
\hline \multirow[b]{2}{*}{ Crop } & \multirow{2}{*}{$\begin{array}{c}\text { Number of } \\
\text { samples } \\
\text { imported }\end{array}$} & \multicolumn{2}{|c|}{ Samples released } & \multicolumn{2}{|c|}{ Samples detained } \\
\hline & & No. & $\%$ & No. & $\%$ \\
\hline $\begin{array}{l}\text { Sorghum } \\
\text { Pearl millet } \\
\text { Pigeon pea } \\
\text { Chickpea } \\
\text { Groundnut }\end{array}$ & $\begin{array}{r}1598 \\
1450 \\
483 \\
7 \\
1342 \\
\end{array}$ & $\begin{array}{r}1313 \\
1440 \\
331 \\
3 \\
963 \\
\end{array}$ & $\begin{array}{l}82.2 \\
99.3 \\
68.5 \\
42.9 \\
71.8\end{array}$ & $\begin{array}{r}285 \\
10 \\
152 \\
4 \\
379\end{array}$ & $\begin{array}{r}17.8 \\
07 \\
31.5 \\
51.1 \\
28.2\end{array}$ \\
\hline Total & 4880 & 4050 & 83.0 & 830 & 17.0 \\
\hline
\end{tabular}

Source: Annual report, 1981 to 1982, Central Plant Protection and Training Institute, Rajendranger, A.P., India.

endangering the new habitat. Therefore, there is something in common between the two disciplines in that they both are necessary and useful.

At ICRISAT, several thousands of germplasm samples are exchanged each year. Table 1 shows the total number of germplasm samples distributed from 1973 to 1983 . All seeds that are exported or imported by ICRISAT must pass through the Indian Government Plant Protection and Quarantine Directorate. The Central Plant Protection Training Institute (CPPTI) at Rajendranagar, Hyderbad, is a part of the Directorate of Plant Protection responsible for the quarantine inspection and release of all ICRISAT seeds. We are fortunate to have such an institute nearby and grateful for their diligent handling and cooperation. In order to further reduce the risk of importing and exporting diseases and pests to and from India, ICRISAT has established a Post Entry Quarantine Isolation Area (PEQIA) and an Export Plant Quarantine Laboratory, which functions in close collaboration with the CPPTI. As an additional safety measure, even after clearance from CPPTI, the imported seeds are sown in this isolation area and scrutinized under the joint supervision of CPPTI and ICRISAT staff during the entire period from germination to harvest. Diseased and pest-infected plants are destroyed and seeds are collected only from healthy plants.

It is reported by CPPTI (1) that a total of 4880 samples of ICRISAT crops were processed by CPPTI for introduction during 1981 to 1982 . The cropwise breakdown and number of released and detained samples is shown in Table 5. However, the number of samples released does not always represent the actual number available at ICRISAT. For example, a very large percentage of pearl millet samples have failed to germinate in PEQIA. Although the CPPTI figure shows a $99.31 \%$ release of pearl millet germplasm in 1981 to 1982 , the actual percent of seeds that reached the ICRISAT gene bank was much less than that. Out of 1121 pearl millet samples that were introduced in 1981 to 1982 from six different countries, 1109 samples were released, of which 506 did not germinate. That means that over $45 \%$ of the samples were lost. This is a very high loss of germplasm compared, for example, to an average of $2 \%$ detention of introduced seeds, screened at the North Central Regional Plant Introduction Station in Ames, IA, as reported by Leppik (14).

$\therefore$. The potential of a germplasm sample is largely unknown at the time of nollection. However, we have seen that a number of desirable 
characters are identified whenever a diverse group of germplasm is evaluated and screened. At times, even those lines that show susceptibility to a disease or pest offer a rare source of breeding material for other agronomically desirable traits. For example, sorghum accessions IS-1082, $2122,2145,4663,4664,5470,5484,5566,18551$, and others have been identified as promising lines for shootfly resistance. However, they are susceptible to grain molds. Other sorghum germplasm lines such as IS$620,621,5959,7237,8219,9308,9482$, and 11234 are promising lines for grain mold resistance; yet they are susceptible to shootfly and stem borer (Hydraecia sp.). Likewise in pigeon pea, ICP-7035 has multiple resistance to wilt and sterility mosaic, but it is susceptible to blight. ICP-7065 is resistant to blight, but highly susceptible to both wilt and sterility mosaic. There are many more examples like these which could have been rejected for one reason, while useful sources for their other traits.

In conclusion, plant quarantine is a very useful and necessary activity. A safe and rapid transfer of germplasm is vital for a sound crop improvement program. A great many exotic crops are flourishing in many areas of the world as a result of international transfer and exchange of germplasm. It is also true that new diseases and pests may be introduced with the germplasm into new areas. Nevertheless, import of small, experimental quantities of seeds with appropriate safeguards based on sound biological principles can often be an answer to improving the genetic base of crops. Much larger quantities of commercial seed often repeatedly enter a country with even greater quarantine risk but often with minimal or cursory inspection. Yet, germplasm is the basic raw material for future development of commercial seed and to impose undue restrictions on its movement appears to be an unnecessary and misguided practice.

Considering the worldwide crop improvement program and in view of the plant breeder's remarkable success in developing high yielding cultivars, it is obvious that there are significant advantages associated with international germplasm exchange. With careful handling, imaginative methods and more specific research on seed pathogen pest relationships, man should be able to save his valuable seeds.

\section{ACKNOWLEDGMENTS}

I wish to thank all my colleagues in the Genetic Resources Unit, and Dr. K. L. Mehra, director of National Bureau of Plant Genetic Resources, ICAR, New Delhi, India, for their assistance in reviewing and improving this paper. I also wish to express my appreciation to the CPPTI and ICRISAT Quarantine Unit for their assistance and cooperation.

\section{REFERENCES}

1. Central Plant Protection Training Institute. 1981-1982 Annual report. Rajendranagar, Hyderabad-500 030, A.P., India.

2. Chiarappa, L., and J. F. Karpati. 1981. Safe and rapid transfer of plant genetic resources: A proposal for a global system. FAO/UNEP/IBPGR Technical conference on Crop Genetic Resources. AGP: 1981/M/6, FAO, Rome. 
3. Cocking, M. R. et al. 1981. Aspects of plant genetic manipulation. Nature 293(5830): 265-270.

4. Gonzalez, H. R. 1977. Entomological. p. 25-28. In W. B. Hewitt and L. Chiarappa (ed.) Plant quarantine in international transfer of genetic resources. CRC Press, Boca Raton, FL.

5. Harlan, J. R. 1975. Crops and man. American Society of Agronomy, and Crop Science Society of America, Madison, WI.

6. Hawkes, J. G. 1981. Germplasm collection, preservation and use. p. 57-83. In K. J. Frey (ed.) Plant breeding II. Iowa State University Press, Ames.

7. Hewitt, W. B. 1977. Pathological. p. 3-16. In W. B. Hewitt and L. Chiarappa (ed.) Plant quarantine in international transfer of genetic resources. CRC Press, Boca Raton, IL.

8. ICRISAT. 1980. Annual report. Genetic Resources Unit, ICRISAT, Patancheru, A.P., India. p. 253-259.

9. --... 1981. Annual report. Genetic Resources Unit, ICRISAT, Patancheru, A.P. India. p. 16-18.

10. International Board for Plant Genetic Resources. 1979. Seed technology for gene banks. AGP: IBPGR/79/31. IBPGR Secretariat, Rome.

11. Jain, H. K. 1982. Plant breeders' rights and genetic resources. Indian J. Genet. 42:121128.

12. Justice, O. L., and L. N. Bass. 1978. Principles and practices of seed storage. USDAAgriculture Handb. no. 506. U.S. Government Printing Office, Washington, DC.

13. Khan, R. P. 1977. Plant quarantine: Principles, methodology, and suggested approaches. p. 289-308. In W. B. Kewitt and L. Chiarappa (ed.) Plant health and quarantine in international transfer of genetic resources. CRS Press, Boca Raton, FL.

14. Leppik, E. E. 1969. List of foreign pests, pathogens, and weeds detected on introduced plants. Plant Introduction Paper no. 15, Beltsville, MD.

15. Maude, R. B. 1973. Seed-borne diseases and their control. p. 325-335. In W. Heydecker (ed.) Seed ecology. Butterworths, Massachusetts.

16. Mehra, K. L., and R. K. Arora. 1982. Plant genetic resources of India-their diversity and conservation. Indian Council of Agricultural Research, National Bureau of Plant Genetic Resources, New Delhi.

17. Mengesha, M. H., and K. E. Prasada Rao. 1981. Current situation and future of sorghum germplasm. p. 323-333. In Sorghum in the eighties; Proc. of the Int. Symposium on Sorghum. 2-7 November. ICRISAT, Patancheru, A.P., India.

18. - 1982. World sorghum germplasm collection and conservation. A paper approved for publication as C.P. No. 141, ICRISAT, Patancheru, A.P., India.

19. Naidu, P. H., and K. K. Nirula. 1979. Quarantine important diseases of sorghum, pearl millet, chickpea, pigeonpea and groundnut. Indian J. Plant Protection VII(2):175-188.

20. Roberts, E. H. 1974. Viability of seeds. Chapman and Hall Ltd., London.

21. Saxena, N. P., and A. R. Sheldrake. 1979. Physiology of growth, development, and yield of chickpeas in India. p. 106-120. In Proc. of the Int. workshop on Chickpea Improvement. 28 February-2 March. ICRISAT, Patancheru, A.P., India. 